\title{
A Study on Metacognitive Thinking Skills of University Students
}

\author{
Yemliha Coşkun \\ Correspondence: Yemliha Coşkun, Assistant Prof. Dr., Sütçü İmam University, Educational Sciences Department, \\ Guidance and Psychological Counseling, Turkey.
}

\author{
Received: January 16, 2018 \\ Accepted: February 5, 2018 \\ Online Published: February 15, 2018 \\ doi:10.11114/jets.v6i3.2931 \\ URL: https://doi.org/10.11114/jets.v6i3.2931
}

\begin{abstract}
The purpose of this study is to investigate the university students' metacognition thinking skills. The research is a descriptive study in the screening model.The study was carried out with 407 students from the faculties of physical education and sports, education science and letters, business administration, theology, engineering, forestry and agriculture at Kahramanmaras Sutcu Imam University during the 2016-2017 academic year. They were selected by convenience sampling method. 'Personal Information Form' and 'Metacognitive Thinking Skills Scale', used as data collection tools. The research data were analyzed through use of SPSS 15.0. The study has concluded that university students have higher levels of metacognitive thinking ability together with their, 'thinking skill, reflective thinking skill intended for problem solving, decision making skill, alternative evaluation' sub dimensions. There has been an increase in the level of metacognitive thinking skill as well as the increase in the class level. Students studying in the faculty of theology were determined to have the highest level of highest metacognitive thinking skills. This was followed by students studying in education, physical education and sports, science-letters, forestry, agriculture and business administration respectively.
\end{abstract}

Keywords: metacognitive thinking skills, üniversity students

\section{Introduction}

Having existed since the Ancient Greeks, metacognition has become a frequently used word in educational psychology recently. In particular, Flavell and other scientists have used the concept of metacognition in their researches on preschool and elementary school children in the 1970s (Flavell, 1979). The term "metacognition" is expressed in various terms such as "metacognitive", "metacognition", "metacognitive knowledge" and "cognitive awareness" in Turkish (Akpunar, 2011). Metacognition which essentially means cognition (Papaleontiou-Louca, 2003) signifies the first order cognitive control and monitoring of cognitive processes. Referring to higher order thinking which includes active control over the cognitive processes engaged in learning (Sonowal and Kalita, 2017), metacognition is explained as one's own knowledge of his/her cognitive processes and outcomes or anything related to them (Flavell, 1976). The metacognitive point of view which originates from the idea of examining the thoughts of the individual about his own thoughts (Karakelle and Saraç, 2010) actually attributes to the second order cognitions: thoughts about thoughts, knowledge about knowledge or actions. Cognition involves perceiving, understanding, remembering and so on, while metacognition is a process which includes one' own perception, understanding, remembering etc. (Papaleontiou-Louca, 2003), and which constitutes the superficial structure of data process and governs and controls the cognitive processes (Altındağ,Senemoğlu, 2013). In other words, it indicates that the individual knows the structure and functioning of his own cognitive system (Tunca, Alkın-Şahin, 2014), knows what he is learning and how to learn it (Altındağ, Senemoğlu, 2013).

According to Flavell (1979), the monitoring of a wide variety of cognitive enterprises occurs through the actions of and interactions among four classes of phenomena: (a) metacognitive knowledge, (b) metacognitive experiences, (c) goals (ortasks), and (d) actions (orstrategies). Metacognitive knowledge is that segment of your (a child's, an adult's) stored world knowledge that has to do with people as cognitive creatures and with their diverse cognitive tasks, goals, actions, and experiences. An example would be a child's acquired belief that unlike many of her friends, she is better at arithmetic than at spelling. Metacognitive experiences are any conscious cognitive or affective experiences that accompany and pertain to any intellectual enterprise. An example would be the sudden feeling that you do not understand something another person just said. He assumes that metacognitive knowledge and metacognitive experiences differ from other kinds only in their content and function, not in their form or quality. Goals (or tasks) refer 
to the objectives of a cognitive enterprise. Actions (orstrategies) refer to the cognitions or other behaviors employed to achieve them.

The reason for the appearance of metacognition in such a foreground in the learning process is the assumption that this ability is effective in ensuring the individual to gain self-learning skills (Akpunar, 2011). Along with the student-centered learning approaches, the learning process of the learners has begun to be taken more into consideration (Tuncer et al., 2016). The "constructivist learning" theory, which has been around in the field of education in recent years, aims to raise students who have an active role in the learning process, who research to get the lowdown, and who can use knowledge they acquire (Tüysüz, Karakuyu, Bilgin, 2008). Current researches have shown the initiation of these metacognitive skills from an early age (SáizManzanares and Carbonero Martín, 2017). In the last few years, researchers in various areas, particularly reading, memory development, and special education, have been showing great interest in exploring the role of cognitive monitoring and other aspects of metacognition in the fulfillment of cognitive tasks. These researchers are of the view that metacognitive beliefs, decisions and actions are the determinants of success or failure in a variety of activities, yet they are frequently overlooked. They believe that successful cognitive performance depends on not only adequate knowledge but also sufficient awareness and control of that knowledge (Garofalo and Lester, 1985). The analyzes have revealed that metacognitive skills are paramount in guiding the learning process (SáizManzanaresand, Carbonero Martín, 2017). Numerous studies have shown that metacognitive awareness plays a significant role in the academic success of students (Zhao and Mo, 2016).Metacognitive skills help students be self-responsible and self-directed and self-regulated (Sonowal and Kalita, 2017; Listiana and et al., 2016), be aware of their learning processes (Shank, 2017), be more conscious and strategic when learning (Zhao and Mo, 2016). It also enables them to make a self-evaluation in the process of acquisitions (Zimmerman and Martinez-Pons, 1988) and accurately measure their performance (Molenberghsand et al., 2016). However, this is a condition related to the competency of the individual to use metacognitive skills. Students need to be aware of their own mental processes and evaluate them (Tunca, Alkın-Şahin, 2014) as individuals show great differences in their metacognitive skills (Molenberghs and et al., 2016). While most of the students' metacognitive skills develop over time, some of them do not (Altındağ, Senemoğlu, 2013). Still, metacognition can be developed and taught through using different strategies in the learning environment (Yıldız\&Akdağ, 2017; Schraw, 1998). Schraw (1998) stated that metacognitive knowledge is multidimensional, domain-general in nature, and teachable, and he identified four instructional strategies for ensuring the construction and acquisition of metacognitive awareness. These are; promoting general awareness, improving self-knowledge and regulatory skills, and encouraging learning environments which are appropriate to the construction and use of metacognition. Teaching metacognitive skills in this sense may provide a remarkable improvement in students' success. Students can learn to think about their own thinking processes and apply learning strategies that will help them to tackle with difficult learning (Altındağ, Senemoğlu, 2013). Upon analyzing the relevant literature, various studies appear to support this view. In their studies conducted with business students, Zhao and Mo (2016) have concluded that metacognitive awareness level is positively correlated with class performance; suggesting that students who have metacognitive-learning awareness perform better without being aware of it. Abdellah (2015) has noted that there is a positive relation between pre-service female teachers' metacognitive awareness and their academic achievement. In the study carried out with secondary school students, Çer \& Sahin (2016) have found that the use of metacognitive strategies in the development of their reading comprehension skills of literary quality books helps those in the experimental group. Likewise, in another study conducted with high school students, a significant negative relationship has been identified between exam anxiety and metacognitive skills, while a significant positive relation has been found between metacognitive skills and academic achievement averages (Isgör, 2016). Thus, metacognition plays a critical role in successful learning (Livingston, 2003). In particular, it is essential that university students have success in their intensive learning activities, that they conduct their studies in a planned and regular manner, and that they have metacognitive awareness about their cognitive processes (Akın et al., 2007). In this regard, the researches to be done will be beneficial for demonstrating the metacognitive awareness profiles of the university students and making the teaching methods and techniques applied in the lessons, the curriculum content and the learning methods and strategies of the students efficient. Hence, this research aims to identify university students' metacognitive skill levels. Depending on the main problem "What is the metacognitive skill level of university students?", the answers to the following questions have been sought.

1.What are the metacognitive thinking skills levels of university students?

2.Do university students' metacognitive thinking skills levels differ across gender?

3.Do university students' metacognitive thinking skills levels differ across class level?

4.Do university students' metacognitive thinking skills levels differ across faculty? 


\section{Method}

\subsection{Research Group}

The research sample holds a total of 407 second, third and fourth grade university students who study at the faculties of physical education and sports, education, science and letters, theology, business administration, engineering, forestry and agriculture at Kahramanmaraş Sütçü İmam University during the 2016 and 2017 academic year. They were selected through convenience sampling method.

Table 1. Demographic Characteristics of the Participants

\begin{tabular}{lll}
\hline Demographic Characteristics & $\mathrm{N}$ & $\%$ \\
\hline Gender & & \\
Female & 239 & 58.7 \\
Male & 168 & 41.3 \\
Faculty /Vocational High School & & \\
Physical Education and Sports & 43 & 10.6 \\
Education & 49 & 12.0 \\
Science-Letters & 90 & 22.1 \\
Theology & 38 & 9.3 \\
Business Administration & 42 & 10.3 \\
Engineering & 45 & 11.1 \\
Forestry & 35 & 8.6 \\
Agriculture & 65 & 16.0 \\
Class Level & & \\
2nd & 25 & 6.1 \\
3rd & 229 & 56.3 \\
4th & 153 & 37.6 \\
\hline
\end{tabular}

Among the participants, $58.7 \%$ were female and $41.3 \%$ were male. Considering faculties, $10.6 \%$ of them are physical education and sports, $12.0 \%$ are education, $22.1 \%$ are science and letters, $9.3 \%$ are theology, $10.3 \%$ are business administration, $11.1 \%$ are engineering, $8.6 \%$ are forestry and $16.0 \%$ are agriculture faculty students. $6.1 \%$ of the participants are in the 2th class, $56.3 \%$ of the participants are in the 3 rd class and $37.6 \%$ are in the 4 th class level.

\subsection{Research Model}

This study, which examines the metacognitive thinking skill levels of university students, is a descriptive study in the screening model.

\subsection{Data Collection Tools}

This research has used "Personal Information Form" developed by the researcher, and "Metacognitive Thinking Skills Scale" developed by Tuncer and Kaysi (2013).

\subsubsection{Personal Information Form}

Personal information form developed by the researcher in order to collect data about the independent variables includes 3 questions in total (gender, faculty or vocational high school, class level).

\subsubsection{Metacognitive Thinking Skills Scale}

The 'Metacognition Thinking Skills Scale' developed by Tuncer and Kaysi (2013) was used as data collection tool in the research. Explanatory and confirmatory factor analysis of the scale was conducted, and Cronbach's Alpha coefficient was calculated as .881 . There are four factors in the scale consisting of 18 items: "thinking ability", "reflective thinking ability for problem solving", "decision making ability" and "alternative evaluation ability". This structure accounts for 56.57 of the total variance. The responses and scoring given to the scale items are of the form 'Strongly Agree=5', 'Agree $=4$ ', 'Undecided=3', 'Disagree $=2$ ' and 'Strongly Disagree=1'.

\subsection{Process}

After the ethics approval of the research, it was realized with 2nd, 3rd, and 4th grade students who read in 9 different faculties at Sütçü İmam University in 2016-2017 academic year. 423students were included in the application, but were excluded from the survey because they were not eligible to score 16 forms in the study. Therefore, the research was conducted with 407 students.

\subsection{Data Analysis}

Data were analyzed through SPSS 15.0 packet statistical program. Arithmetic mean, frequency, standard deviation and percentage distributions were calculated in order to determine participants' socio-demographic characteristics, and metacognition thinking skills. Independent samples t-test to reveal the difference in metacognition thinking skillslevels in terms of gender. Besides, Kruskal-Wallis H-test was used to determine the difference in metacognition thinking skills levels depending on class level and faculty. Significance level was taken as 0.05 . 


\section{Findings}

The arithmetic mean and standard deviation values of the üniversity students' metacognitive thinking skill levels are presented in Table 2 .

Table 2. Arithmetic Mean and Standard Deviations Values of University Students' Metacognitive Thinking Skills Level

\begin{tabular}{llll}
\hline Variables & N & Arithmetic Mean & Standard Deviation \\
\hline 1.Thinking SkillLevel & 407 & 20.72 & 3.93 \\
2. Reflective Thinking Skill Intended forProblem & 407 & 19.18 & 4.11 \\
Solvinglevel & & & 3.60 \\
3. Decision Making Skill level & 407 & 15.98 & 3.48 \\
4. Alternative Evaluation Skill & 407 & 15.54 & 13.09 \\
5. The overall scale & 407 & 71.44 & \\
\hline
\end{tabular}

Table 2 depicts that the students have 20.72 arithmetic mean scores and 3.93 standard deviations of their thinking skill level; 19.18arithmetic mean scores and 4.11 standard deviations of their reflective thinking skill intended for problem solving level; 15.98arithmetic mean scores and 3.60 standard deviations of their decision making skill level; 15.54arithmetic mean scores and 3.48 standard deviations of their alternative evaluation skill, while that of the arithmetic mean and standard deviation of their all metacognitive thinking skill scale scores is 71.44 and 13.09, respectively. Accordingly, it is likely to mention that students' metacognitive thinking skill levels are high.

Table 3. Arithmetic Mean and Standard Deviation Values of Students' Metacognitive Thinking Skills Level by Faculty

\begin{tabular}{llll}
\hline Faculties & $\mathrm{N}$ & Arithmetic Mean & Standard Deviation \\
\hline Theology & 38 & 76.63 & 10.43 \\
Education & 49 & 74.97 & 10.91 \\
Physical education and sports & 43 & 74.67 & 10.43 \\
Science-Letters & 90 & 73.67 & 12.64 \\
Forestry & 35 & 71.02 & 8.65 \\
Agriculture & 65 & 70.47 & 13.29 \\
Business Administration & 42 & 65.95 & 16.10 \\
Engineering & 45 & 62.53 & 15.19 \\
\hline
\end{tabular}

Upon analyzing students' metacognitive thinking skill level scores by faculty, theology faculty students possess the highest mean, which is respectively followed by those from the faculties of education, physical education and sports, science and letters, forestry, agriculture, business administration and engineering.

Table 4. Independent Group t-test Results of Meta Cognitive Thinking Skills Level of University Students in terms of Gender

\begin{tabular}{|c|c|c|c|c|c|c|c|}
\hline Variables & Gender & $\mathrm{N}$ & Mean & Std. Deviation & $\mathrm{df}$ & $\mathrm{t}$ & $\mathrm{p}$ \\
\hline \multirow[t]{2}{*}{ 1.Thinking SkillLevel } & Female & 239 & 21.23 & 3.46 & 301.17 & 2.97 & .003 \\
\hline & Male & 168 & 20.01 & 4.44 & & & \\
\hline \multirow[t]{2}{*}{ 2. Reflective Thinking Skill Intended for Problem Solvinglevel } & Female & 239 & 19.80 & 3.73 & 317.70 & 3.57 & .000 \\
\hline & Male & 168 & 18.30 & 4.46 & & & \\
\hline \multirow[t]{2}{*}{ 3. Decision Making Skill level } & Female & 239 & 16.60 & 3.25 & 317.50 & 4.10 & .000 \\
\hline & Male & 168 & 15.10 & 3.89 & & & \\
\hline \multirow[t]{2}{*}{ 4. Alternative Evaluation Skill } & Female & 239 & 16.13 & 3.09 & 309.50 & 4.00 & .000 \\
\hline & Male & 168 & 14.70 & 3.83 & & & \\
\hline \multirow[t]{2}{*}{ 5. The overall scale } & Female & 239 & 73.78 & 11.74 & 315.10 & 4.24 & .000 \\
\hline & Male & 168 & 68.12 & 14.20 & & & \\
\hline
\end{tabular}

As seen in Table 4, a significant difference has been noted between students' thinking skill level scores $(\mathrm{t}=2,97 ; \mathrm{p}<.01)$; reflective thinking skill intended for problem solving level $(\mathrm{t}=3,57 ; \mathrm{p}<.01)$; decision making skill level $(\mathrm{t}=4,10 ; \mathrm{p}<.01)$; alternative evaluation skill $(\mathrm{t}=4,10 ; \mathrm{p}<.01)$ and the all metacognitive thinking skill scales $\operatorname{cores}(\mathrm{t}=4,24$; $\mathrm{p}<.01$ )depending upon gender in favor of female students. 
Table 5. Kruskal Wallis-H Test Results of University Students' Metacognitive Thinking Skills Levels in terms of Class Level

\begin{tabular}{|c|c|c|c|c|c|c|c|}
\hline Variables & Class & $\mathrm{N}$ & Mean Rank & $\mathrm{df}$ & $\mathrm{X}^{2}$ & $\mathrm{p}$ & $\begin{array}{l}\text { Significant } \\
\text { difference }\end{array}$ \\
\hline \multirow[t]{3}{*}{ 1.Thinking SkillLevel } & 2nd & 25 & 161.88 & \multirow[t]{3}{*}{2} & \multirow[t]{3}{*}{9.03} & \multirow[t]{3}{*}{.011} & $4>2$ \\
\hline & $3 \mathrm{rd}$ & 229 & 195.23 & & & & $4>3$ \\
\hline & 4th & 153 & 224.01 & & & & \\
\hline \multirow{3}{*}{$\begin{array}{l}\text { 2. Reflective Thinking } \\
\text { Skill Intended forProblem } \\
\text { Solvinglevel }\end{array}$} & 2nd & 25 & 163.34 & \multirow[t]{3}{*}{2} & \multirow[t]{3}{*}{11.05} & \multirow[t]{3}{*}{.004} & $4>2$ \\
\hline & $3 \mathrm{rd}$ & 229 & 192.94 & & & & $4>3$ \\
\hline & 4th & 153 & 227.20 & & & & \\
\hline \multirow{3}{*}{$\begin{array}{l}\text { 3. Decision Making Skill } \\
\text { level }\end{array}$} & 2nd & 25 & 173.60 & \multirow[t]{3}{*}{2} & \multirow[t]{3}{*}{11.49} & \multirow[t]{3}{*}{.003} & $4>2$ \\
\hline & $3 \mathrm{rd}$ & 229 & 190.82 & & & & $4>3$ \\
\hline & 4th & 153 & 228.70 & & & & \\
\hline \multirow{3}{*}{$\begin{array}{l}\text { 4.Alternative } \quad \text { Evaluation } \\
\text { Skill }\end{array}$} & 2nd & 25 & 164.86 & \multirow[t]{3}{*}{2} & \multirow[t]{3}{*}{10.24} & \multirow[t]{3}{*}{.006} & $4>2$ \\
\hline & $3 \mathrm{rd}$ & 229 & 193.40 & & & & $4>3$ \\
\hline & 4th & 153 & 226.26 & & & & \\
\hline \multirow[t]{3}{*}{ 5. The overall scale } & 2nd & 25 & 162.14 & \multirow[t]{3}{*}{2} & \multirow[t]{3}{*}{13.48} & \multirow[t]{3}{*}{.001} & $4>2$ \\
\hline & $3 \mathrm{rd}$ & 229 & 191.11 & & & & $4>3$ \\
\hline & 4th & 153 & 230,13 & & & & \\
\hline
\end{tabular}

'Kruskal Wallis-H' test shows that there exists a statistically significant difference between students' level of thinking skill $\left(x^{2}=9.03 ; p<.05\right)$; level of reflective thinking skill intended for problem solving $\left(x^{2}=11.05 ; p<.01\right)$; level of decision making skill $\left(x^{2}=11.49 ; p<.01\right)$; level of alternative evaluation skill $\left(x^{2}=10.24 ; p<.01\right)$ and level of the overall scale $\left(\mathrm{x}^{2}=13.48 ; \mathrm{p}<.01\right)$ depending on their class level. 'Mann Whitney-U' test reveals that students from the $4^{\text {th }}$ class students have higher levels of thinking skill level; reflective thinking skill; decision making skill level; alternative evaluation skill and the overall scale compared to those from the $2^{\text {nd }}$ and $3^{\text {rd }}$ class students.

'Kruskal Wallis-H' test shows that there exists a statistically significant difference between students' level of thinking skill $\left(\mathrm{x}^{2}=25.71 ; \mathrm{p}<.01\right)$; level of reflective thinking skill intended for problem solving $\left(\mathrm{x}^{2}=33.82 ; \mathrm{p}<.01\right)$; level of decision making skill $\left(x^{2}=31,03 ; p<.01\right)$; level of alternative evaluation skill $\left(x^{2}=31.37 ; p<.01\right)$ and level of the overall scale $\left(\mathrm{x}^{2}=37.71 ; \mathrm{p}<.01\right)$ ran order depending on their faculties. 'Mann Whitney- $\mathrm{U}$ ' test reveals that students from the physical education and sports department; education; science and letters; theology; forestry and agriculture faculty students have higher levels of thinking skill compared to those from the faculties of engineering; besides the level of thinking ability of the students of theology faculty is higher than those of the business administration, forestry, and agriculture faculty students. It seems that engineering faculty students are at a higher level than the agriculture faculty students. In terms of level of reflective thinking skill intended for problem solving, physical education and sports department students are higher than engineering and agriculture faculty students; education faculty students are higher than business administration, engineering and agriculture faculty students; science and letters faculty students are higher than engineering faculty students; theology faculty students are higher than engineering, forestry, and agriculture faculty students; forest faculty students are higher than engineering faculty students and agriculture faculty students are higher than engineering faculty students. In terms of level of decision making skill,physical education and sports department students are higher than business administration and engineering faculty students; education faculty students are higher than business administration and engineering faculty students; science and letters faculty students are higher than business administration, engineering and agriculture faculty students; theology faculty students are higher than physical education and sports department, business administration, engineering, forest and agriculture faculty students; forest faculty students are higher than engineering faculty students. In terms of level of alternative evaluation skill, physical education and sports department students are higher than business administration, engineering and forest faculty students; education faculty students are higher than business administration, engineering and forest faculty students; science and letters faculty students are higher than business administration and engineering faculty students; theology faculty students are higher than business administration and engineering faculty students; agriculture faculty students are higher than business administration and engineering faculty students. In terms of level of the overall scale, physical education and sports department students are higher than business administration, engineering and forest faculty students; education faculty students are higher than business administration, engineering and forest faculty students; science and letters faculty students are higher than business administration and engineering faculty students; theology faculty students are higher than business administration, engineering, forest and agriculture faculty students; forest faculty and agriculture faculty students are higher than engineering faculty students. 
Table 6. Kruskal Wallis-H Test Results of University Students' Metacognitive Thinking Skills Levels in terms of Faculty

\begin{tabular}{|c|c|c|c|c|c|c|c|}
\hline Variables & Faculty & $\mathrm{N}$ & $\begin{array}{l}\text { Mean } \\
\text { Rank }\end{array}$ & $\mathrm{df}$ & $\mathrm{X}^{2}$ & $\mathrm{p}$ & $\begin{array}{l}\text { Significant } \\
\text { difference }\end{array}$ \\
\hline \multirow[t]{8}{*}{ 1.Thinking SkillLevel } & $\begin{array}{l}\text { A-Physical education } \\
\text { and sports }\end{array}$ & 43 & 218.90 & 7 & 25.71 & .001 & \multirow{8}{*}{$\begin{array}{l}\mathrm{A}>\mathrm{F} \\
\mathrm{B}>\mathrm{F} \\
\mathrm{C}>\mathrm{F} \\
\mathrm{D}>\mathrm{E}, \\
\mathrm{D}>\mathrm{G}, \mathrm{D}>\mathrm{H} \\
\mathrm{G}>\mathrm{F} \\
\mathrm{H}>\mathrm{F}\end{array}$} \\
\hline & B- Education & 49 & 201.64 & & & & \\
\hline & C-Science-Letters & 90 & 224.79 & & & & \\
\hline & D- Theology & 38 & 253.71 & & & & \\
\hline & $\begin{array}{l}\text { E- Business } \\
\text { Administration }\end{array}$ & 42 & 184.27 & & & & \\
\hline & F- Engineering & 45 & 141.43 & & & & \\
\hline & G- Forestry & 35 & 182.96 & & & & \\
\hline & H- Agriculture & 65 & 204.72 & & & & \\
\hline \multirow{8}{*}{$\begin{array}{l}\text { 2. Reflective Thinking Skill Intended for } \\
\text { Problem Solving level }\end{array}$} & $\begin{array}{l}\text { A-Physical education } \\
\text { and sports }\end{array}$ & 43 & 233.85 & 7 & 33.82 & .000 & \multirow{8}{*}{$\begin{array}{l}\mathrm{A}>\mathrm{F}, \mathrm{A}>\mathrm{H} \\
\mathrm{B}>\mathrm{E}, \mathrm{B}>\mathrm{F}, \mathrm{B}>\mathrm{H} \\
\mathrm{C}>\mathrm{F} \\
\mathrm{D}>\mathrm{F}, \mathrm{D}>\mathrm{G}, \mathrm{D}>\mathrm{H} \\
\mathrm{G}>\mathrm{F} \\
\mathrm{H}>\mathrm{F}\end{array}$} \\
\hline & B- Education & 49 & 240.40 & & & & \\
\hline & C- Science-Letters & 90 & 219.86 & & & & \\
\hline & D- Theology & 38 & 234.71 & & & & \\
\hline & $\begin{array}{l}\text { E- Business } \\
\text { Administration }\end{array}$ & 42 & 184.88 & & & & \\
\hline & F- Engineering & 45 & 127.16 & & & & \\
\hline & G- Forestry & 35 & 194.73 & & & & \\
\hline & H- Agriculture & 65 & 187.48 & & & & \\
\hline \multirow[t]{8}{*}{ 3. Decision Making Skill level } & $\begin{array}{l}\text { A-Physical education } \\
\text { and sports }\end{array}$ & 43 & 208.41 & 7 & 31.03 & .000 & \multirow{8}{*}{$\begin{array}{l}\mathrm{A}>\mathrm{E}, \mathrm{A}>\mathrm{F} \\
\mathrm{B}>\mathrm{E}, \mathrm{B}>\mathrm{F} \\
\mathrm{C}>\mathrm{E}, \mathrm{C}>\mathrm{F}, \mathrm{C}>\mathrm{H} \\
\mathrm{D}>\mathrm{A}, \mathrm{D}>\mathrm{E}, \quad \mathrm{D}>\mathrm{F}, \\
\mathrm{D}>\mathrm{G}, \mathrm{D}>\mathrm{H} \\
\mathrm{G}>\mathrm{F}\end{array}$} \\
\hline & B- Education & 49 & 224.14 & & & & \\
\hline & C-Science-Letters & 90 & 229.57 & & & & \\
\hline & D- Theology & 38 & 256.42 & & & & \\
\hline & $\begin{array}{l}\text { E- Business } \\
\text { Administration }\end{array}$ & 42 & 154.99 & & & & \\
\hline & F- Engineering & 45 & 151.31 & & & & \\
\hline & G- Forestry & 35 & 198.24 & & & & \\
\hline & H- Agriculture & 65 & 191.10 & & & & \\
\hline \multirow[t]{8}{*}{ 4. Alternative Evaluation Skill } & $\begin{array}{l}\text { A-Physical education } \\
\text { and sports }\end{array}$ & 43 & 243.88 & 7 & 31.37 & .000 & \multirow{8}{*}{$\begin{array}{l}\mathrm{A}>\mathrm{E}, \mathrm{A}>\mathrm{F}, \mathrm{A}>\mathrm{G} \\
\mathrm{B}>\mathrm{E}, \mathrm{B}>\mathrm{F}, \mathrm{B}>\mathrm{G} \\
\mathrm{C}>\mathrm{E}, \mathrm{C}>\mathrm{F} \\
\mathrm{D}>\mathrm{E}, \mathrm{D}>\mathrm{F} \\
\mathrm{H}>\mathrm{E}, \mathrm{H}>\mathrm{F}\end{array}$} \\
\hline & B- Education & 49 & 239.71 & & & & \\
\hline & C- Science-Letters & 90 & 220.26 & & & & \\
\hline & D- Theology & 38 & 217.21 & & & & \\
\hline & $\begin{array}{l}\text { E- Business } \\
\text { Administration }\end{array}$ & 42 & 156.14 & & & & \\
\hline & F- Engineering & 45 & 146.18 & & & & \\
\hline & G- Forestry & 35 & 179.81 & & & & \\
\hline & H- Agriculture & 65 & 204.44 & & & & \\
\hline \multirow[t]{8}{*}{ 5. The overall scale } & $\begin{array}{l}\text { A-Physical education } \\
\text { and sports }\end{array}$ & 43 & 231.22 & 7 & 37.71 & .000 & \multirow{8}{*}{$\begin{array}{l}\mathrm{A}>\mathrm{E}, \mathrm{A}>\mathrm{F}, \mathrm{A}>\mathrm{G} \\
\mathrm{B}>\mathrm{E}, \mathrm{B}>\mathrm{F}, \mathrm{B}>\mathrm{G} \\
\mathrm{C}>\mathrm{E}, \mathrm{C}>\mathrm{F}, \mathrm{C}>\mathrm{G} \\
\mathrm{D}>\mathrm{E}, \quad \mathrm{D}>\mathrm{F}, \quad \mathrm{D}>\mathrm{G}, \\
\mathrm{D}>\mathrm{H} \mathrm{G}>\mathrm{F} \\
\mathrm{H}>\mathrm{F}\end{array}$} \\
\hline & B- Education & 49 & 230.91 & & & & \\
\hline & C-Science-Letters & 90 & 228.64 & & & & \\
\hline & D- Theology & 38 & 248.30 & & & & \\
\hline & $\begin{array}{l}\text { E- Business } \\
\text { Administration }\end{array}$ & 42 & 159.29 & & & & \\
\hline & F- Engineering & 45 & 134.93 & & & & \\
\hline & G- Forestry & 35 & 178.99 & & & & \\
\hline & H- Agriculture & 65 & 195.87 & & & & \\
\hline
\end{tabular}

\section{Discussion}

Educational phenomenon is a struggle for individuals to gain the desired behaviors. However, many factors are influential in the realization of education and during the learning process of individuals. Some of them are related to the environment in which individuals live, while others are associated with themselves. Even if the same curriculum is applied, individual differences exist in the outcomes and productivity. One of the reasons for this is the metacognitive thinking skill of the individuals. Individuals with metacognitive thinking skills, which are considered as an improvable skill, are likely to be more successful in the cognitive efforts engaged in education. Thus, the training efforts will be made more productive for both the individual and the institution. Therefore, determining the metacognitive skill level of 
the youth as a part of education is of utmost importance for promoting students to gain metacognitive awareness along with the development and implementation of strategies in the improvement of this ability.

Upon analyzing the findings of the present study, university students have been found to possess higher levels of metacognitive thinking skills together with sub-dimensions of thinking skill, reflective thinking skill, intended for problem solving, decision making skill, alternative evaluation. Considering the related literature, Adigüzel and Orhan (2017a); Nazik and etc. (2014), Adigüzel and Orhan (2017b.) and Kana (2015); Alkan and Erdem (2012) have determined that university students have higher levels of metacognitive thinking skills. This result suggests that the cognitive strategies that university students in the last stage of the education system have learned in the process of preparing for the university entrance exams and the knowledge they have gained in the fields where they have to specialize in universities have contributed significantly to their metacognitive thinking skills. Moreover, findings related to the class level are in line with this result. Research results have also revealed that there is an increase in the level of metacognitive thinking skills including all sub-dimensions depending on the moving up. It may be wise to mention that students become much more competent in conducting metacognitive strategies in their cognitive efforts as the class level increases. Tüysüz, Karakuyu, Bilgin (2008) have found that prospective teachers' metacognition levels increase as the class level increases. Similar results have emerged in Gül, Özay and Sadi's study (2015).The results of the current research have suggested that participants' overall metacognitive thinking skills and the sub-dimensions of thinking skill, reflective thinking skill intended forproblem solving, decision making skill, alternative evaluation differ across gender. The difference has been found to be in favor of female students. This indicates that female students are able to control their thinking processes better than male students, and they are more successful in developing metacognitive strategies. Considering the relevant literature, various studies have achieved similar results. In their studies conducted with university students, Ateş (2013); Kana (2015); Küçük Kılıç, Cihan and Öncü (2015), Gül, Özay and Sadi (2015) have concluded that average scores of female participants in metacognitive learning strategies were higher compared to those of males. Adıgüzel and Orhan (2017) have carried out a research on university students attending basic English course and found that students metacognitive skill levels differed in favor of female students. Besides, Baykara (2011) has determined no significant difference between university students' metacognitive total scores in terms of gender. Likewise, no significant difference has been identified between university students' metacognitive thinking skills depending on gender in the studies of Tüysüz, Karakuyu, Bilgin (2008); Bakioğlu et al., (2015), Ayazgök and Aslan (2014). When the literature has been analyzed, findings are available related to the difference between students' metacognitive thinking skills in terms of gender, while some findings show that female students have higher levels of metacognitive thinking skills compared to males. Thus, it is likely that there is a positive perception in favor of females regarding metacognitive thinking skills. Similar studies may be conducted to make the situation more precise.

Research results have also shown that theology and education faculty, physical education and sports high school students' metacognitive thinking skill levels are higher than other faculties. This may result from the fact that students are exposed to different types of scoring types during the entrance to these faculties and that the content of the education they receive may lead to a difference in their cognitive structures. As a matter of fact, the aim of the education activities of the students from all these faculties is to provide a direct service for people. There is a need for a more active, dynamic and strategic intellectual structure, rather than static, as a requirement for interactions with people. Therefore, that the metacognitive skill levels of students studying at the direct human-oriented departments are higher than those who study in other faculties is an expected result. Several studies have also revealed significant differences among faculties in terms of metacognitive thinking skills. Demir, Kaymak Ö. (2011) and Bakioğlu et al., (2015) have determined significant differences between students' metacognitive thinking skills of the students in terms of faculty. In addition, research results show that students' metacognitive thinking skills do not vary across faculties (Aljaberi \& Gheith, 2015).

As a result, university students' high level of metacognitive thinking skills may be stated to be an important anticipation related to the educational process. The findings indicate that the education programs are successful in such a way that the students' own and their educators' efforts succeed in raising students with metacognitive thinking skills. This success will not only be an inseparable part of the educational process, but also an invaluable contribution to the students' professional competencies and achievements. Therefore, it is highly significant for the stakeholders to maintain and develop this success during the university education process. It will also be useful to conduct researches with different educational institutions and different socio-demographic conditions in respect of raising awareness.

\section{References}

Abdellah, R. (2015). Metacognitive awareness and its relation to academic achievement and teaching performance of pre-service female teachers in Ajman University in UAE, Procedia-Social and Behavioral Sciences, 174, 560-567. https://doi.org/10.1016/j.sbspro.2015.01.707 
Adıgüzel, A., \& Orhan, A. (2017a). The relation between English learning students' levels of self-regulation and metacognitive skills and their English academic achievements, Journal of Education and Practice, 8(9), 115-125.

Adıgüzel, A., \& Orhan, A. (2017b). Öğrencilerin üstbiliş beceri düzeyleri ile İngilizce dersine ilişkin akademik başarıları arasındaki ilişki, Ihlara Eğitim Araştırmaları Dergisi, 2(1), 5-14.

Akın, A., Abacı, R., \& Çetin, B. (2007). Bilişötesi Farkındalık Envanteri’ninTürkçe Formunun Geçerlik ve Güvenirlik Çalışması. Kuram ve Uygulamada Eğitim Bilimleri / Educational Sciences: Theory \& Practice, 7(2), 655-680.

Akpunar, B. (2011). The analysis of the concept of cognition and metacognition in terms of the philosophy of mind, Turkish Studies - International Periodical For The Languages, Literature and History of Turkish or Turkic, 6(4), 353-365.

Aljaberi, N. M., \& Gheith, E. (2015). University students' level of metacognitive thinking and their ability to solve problems. American International Journal of Contemporary Research, 5(3), 121-134.

Alkan, F., \& Erdem, E. (2012). A Study on the metacognitive awareness of prospective teachers, Atatürk Üniversitesi, Kazım Karabekir Eğitim Fakültesi Dergisi, 25.

Altındağ, M., \& Senemoğlu, N. (2013). Metacognitive skills scale, H. U. Journal of Education, 28(1), 15-26.

Ateş, A. (2013). Üniversite Öğrencilerinin okuma stratejileri üstbilişsel farkındalık düzeyleri (İnönü Üniversitesi örneği), Uluslararası Türkçe Edebiyat Kültür Eğitim Dergisi, International Journal of Turkish Literature Culture Education, 2(4), 258-273. https://doi.org/10.7884/teke.223

Ayazgök, B., \& Aslan, H. (2014). The review of academic perception, level of metacognitive awareness and reflective thinking skills of science and mathematic üniversity students, Procedia - Social and Behavioral Sciences, 141, 781-790. https://doi.org/10.1016/j.sbspro.2014.05.137

Bakioğlu, B., Alkış, K. M., Karamustafaoğlu, O., Uluçınar, S. Ş., Akman, E., Ersanlı, E., \& Çakır, R. (2015). Öğretmen adaylarının bilişötesi farkındalık düzeyi, problem çözme becerileri ve teknoloji tutumlarının incelenmesi, Trakya Üniversitesi Ĕ̈itim Fakültesi Dergisi, 5(1), 22-33.

Baykara, K. (2011). A study on "teacher efficacy perceptions" and "metacognitive learning strategies' of prospective teachers.H. U. Journal of Education, 40, 80-92.

Çer, E., \& Sahin, E. (2016). Improving reading comprehension skills with children's books through metacognitive strategy: The Turkish Context, Journal of Education and Training Studies, 4(9), 109-119. https://doi.org/10.11114/jets.v4i9.1566

Demir, Ö., \& Kaymak, Ö. S. (2011). Üniversite öğrencilerinin üst biliş düzeylerinin çeşitli değişkenler açısından incelenmesi, Ç.Ü. Sosyal Bilimler Enstitüsü Dergisi, 20(3), 145-160.

Flavell, J. H. (1976). Metacognitive aspects of problem solving. In: Resnick, L.B., (Ed.), The Nature of Intelligence, Lawrence Erlbaum Associates, Hillsdale, 231-235.

Flavell, J. H. (1979). Metacognition and cognitive monitoring: A new area of cognitive developmental inquiry. American Psychologist, 34(10), 906-911. https://doi.org/10.1037/0003-066X.34.10.906

Garofalo, J., \& Lester, F. K. Jr. (1985). Metacognition, cognitive monitoring, and mathematical performance, Journal for Research in Mathematics Education, 16(3), 163-176. https://doi.org/10.2307/748391

Gül, Ş., Özay K., E., \& Yılmaz, S. Y. S. (2015). Biyoloji öğretmeni adaylarının üstbiliş farkındalıklarının farklı değişkenler açısından incelenmesi, Hasan Ali YücelEğitim FakültesiDergisi, 12-1(23), 83-91.

Isgör, I. Y. (2016). Metacognitive skills, academic success and exam anxiety as the predictors of psychological well-being, Journal of Education and Training Studies, 4(9), 35-42. https://doi.org/10.11114/jets.v4i9.1607

Kana, F. (2015). Türkçe öğretmeniadaylarının üstbiliş farkındalık düzeyleri, Akademik Sosyal Araştırmalar Dergisi, 3(17), 66-81.

Karakelle, S., \& Saraç, S. (2010). Üst biliş hakkında bir gözden geçirme: Üstbiliş çalışmaları mı yoksa üst bilişsel yaklaşım mı? Türk Psikoloji Yazıları, 13(26), 45-60.

Küçük, K. S., Cihan, H., \& Öncü, E. (2015). Metacognitive learning strategies and academic self-efficacy of pre-service physical education teachers and their attitudes towards the profession of teaching, Spor.Bilimleri. Dergisi, Hacettepe Journal of Sport Sciences, 26(3), 77-89. 
Listiana, L., Susilo, H., Suwono, H., \& Suarsini, E. (2016). Empowering students' metacognitive skills through new teaching strategy (Group investigation integrated with think talk write in biology classroom, Journal of Baltic Science Education, 15(3), 391-400.

Livingston, J. A. (2003). Metacognition: An overview, https://eric.ed.gov/?id=ED474273, ERIC Number: ED474273.

Molenberghs, P., Trautwein, F. M., Böckler, A., Singer, T., \& Kanske, P. (2016). Neural correlates of metacognitive ability and of feeling confident: a large-scale fMRI study. Social Cognitive \& Affective Neuroscience, 11(12), 1942-1951. https://doi.org/10.1093/scan/nsw093

Nazik, F., Sönmez, M., \& Güneş, G. (2014). Hemşirelik öğrencilerinin üstbiliş düzeylerinin çeşitli değişkenler açısından incelenmesi, Anadolu Hemşirelik ve Sağlık Bilimleri Dergisi, 17(3), 145-150.

Papaleontiou-Louca, E. (2003). The concept and instruction of metacognition, Teacher development, 7(1), 9-30. https://doi.org/10.1080/13664530300200184

Rowlands, S. (2009). The importance of cultivating a metadiscourse in deliberate support of metacognition. In: Clayton B. Larson (Ed.) Metacognition: New Research Developments, Nova Science Publishers, Inc. Newyork, 1-22.

Sáiz, M. M. C., \& Carbonero, M. M. Á. (2017). Metacognitive precursors: An analysis in children with different disabilities, Brain Sciences, 7(10), 1-14. https://doi.org/10.3390/brainsci7100136

Schraw, G. (1998). Promoting general metacognitive awareness. Instructional Sciences, 26, 113-125. https://doi.org/10.1023/A:1003044231033

Shank, P. (2017). Self-Sufficient learners make successful workers, TD. Talent Development, 71(4), 42-46.

Sonowal, M., \& Kalita, M. (2017). A study on metacognitive awareness and academic achievement of higher secondary level students of Dibrugarh town of Assam, India. TheClarion: International Multidisciplinary Journal, 6(1), 69-74. https://doi.org/10.5958/2277-937X.2017.00012.0

Sünbül, A. M. (2004). Düşünme stilleri ölçeğinin geçerlik ve güvenirliği. The validity reliability of the thinking styles scale, Eğitim ve Bilim/Educalion and Science, 29(132), 25-42.

Tunca, N., \& Alkın-Şahin, S. (2014). Öğretmen adaylarının bilişötesi (ÜstBiliş) öğrenme stratejileri ile akademik özyeterlik inançları arasındaki ilişki. Anadolu Journal of Educational Sciences International, 4(1), 47-56. https://doi.org/10.18039/ajesi.89592

Tuncer, M., \& Kaysi, F. (2013). Öğretmen adaylarının üstbiliş düşünme becerileri açısından değerlendirilmesi, Turkish Journal of Education (TURJE), 2(4), 44-54.

Tuncer, M., Berkant, H. G., Bilgin, B., \& Tanaş, R. (2016). Meslek yüksekokulu öğrencilerinin üst biliş düşünme becerileri açısından değerlendirilmesi, Adlyaman Üniversitesi Sosyal Bilimler Enstitüsü Dergisi, 8(24), 1121-1142.

Tüysüz, C., Karakuyu, Y., \& Bilgin, İ. (2008). Öğretmen adaylarının üstbiliş düzeylerinin belirlenmesi, Abant İzzet Baysal Üniversitesi Sosyal Bilimler Enstitüsü Dergisi - Journal of Social Sciences, 2(17), 147-158.

Yıldız, H., \& Akdağ, M. (2017). The effect of metacognitive strategies on prospective teachers' metacognitive awareness and self efficacy belief, Journal of Education and Training Studies, 5(12), 30-40. https://doi.org/10.11114/jets.v5i12.2662

Zhao, L., \& Mo, S. (2016). The impact of metacognitive awareness on class performance in financial accoutning courses. Academy of Educational Leadership Journal,20(2), 78-88.

Zimmerman, B. J., \& Martinez-Pons, M. (1988). Construct validation of a strategy model of student self-regulated learning, Journal of Educational Psvchology, 80(3), 284-290. https://doi.org/10.1037/0022-0663.80.3.284

\section{Copyrights}

Copyright for this article is retained by the author(s), with first publication rights granted to the journal.

This is an open-access article distributed under the terms and conditions of the Creative Commons Attribution license which permits unrestricted use, distribution, and reproduction in any medium, provided the original work is properly cited. 